\title{
PENINGKATAN HASIL BELAJAR DENGAN MODEL PEMBELAJARAN INKUIRI TERBIMBING PADA SISWA KELAS XI SMA NEGERI 1 DAMPELAS
}

\author{
Dian Vitayana, Yusuf Kendek dan Fihrin
}

e-mail: Dianvitayana@ymail.com

Program Studi Pendidikan Fisika FKIP Universitas Tadulako

Jl. Soekarno Hatta Km. 9 Kampus Bumi Tadulako Tondo Palu - Sulawesi Tengah

\begin{abstract}
Abstrak - Tujuan dalam penelitian ini adalah untuk mengetahui peningkatan hasil belajar siswa dengan model pembelajaran inkuiri terbimbing. Penelitian ini merupakan penelitian kuasi eksperimen dengan menggunakan desain pretest-postest. Sampel penelitian ini adalah siswa kelas XI MIA 1 sebagai kelas eksperimen dengan jumlah siswa 31 orang dan kelas XI MIA 2 sebagai kelas kontrol dengan jumlah siswa 30 orang. Dalam penelitian ini data dikumpulkan melalui tes hasil belajar siswa. Data pretest dan postest kelompok eksperimen dan kontrol dianalisis menggunakan analisis statistik. Skor rata-rata tes hasil belajar fisika yang diperoleh untuk kelas eksperimen adalah 10,52 dan kelas kontrol 7,57. Dari hasil uji t pada taraf nyata a $=0,05$ dan dk $=59$. Diperoleh $t_{\text {hit }}=4,40$ dan $t_{\text {tabel }}=1,67$, dengan demikian Ho ditolak dan $\mathrm{H}_{1}$ diterima. Dari hasil $\mathrm{N}$-Gain ratarata diperoleh $44,08 \%$ dan termasuk dalam kategori sedang. Sedangkan, pada kelas kontrol diperoleh $\mathrm{N}$-gain rata-rata $11,30 \%$ yang termasuk dalam kategori rendah. Berdasarkan uji hipotesis dan N-Gain rata-rata, dapat disimpulkan bahwa terdapat peningkatan hasil belajar dengan model pembelajaran inkuiri terbimbing pada siswa kelas XI MIA SMA Negeri 1 Dampelas.
\end{abstract}

Kata Kunci : Model pembelajaran Inkuiri terbimbing, Peningkatan hasil belajar.

\section{PENDAHULUAN}

Segala hal yang ada disekitar kita menjadi informasi atau pengetahuan dan bahkan menjadi bagian dari pengalamn hidup kita. Pengetahuan atau knowledge secara umum dapat diartikan sebagai suatu hal yang diketahui. Sumber-sumber pengetahuan meliputi: (1) Pengalaman (experience), (2) kewenangan (authority), (3) berpikir deduktif (deductive thinking), (4) berpikir induktif (inductive thinking), dan (5) pendekatan ilmiah

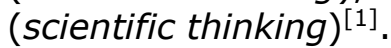

Di dalam proses belajar mengajar tercakup komponen, pendekatan, dan berbagai metode pengajaran yang dikembangkan dalam proses tersebut. Tujuan utama diselenggarakannya proses belajar adalah demi tercapainya tujuan pembelajaran. Dan tujuan tersebut utamanya adalah keberhasilan siswa belajar baik itu dalam suatu mata pelajaran tertentu. Salah satu contohnya yaitu pelajaran fisika.

Permasalahan besar dalam proses pembelajaran saat ini adalah kurangnya usaha pengembangan berpikir yang menuntun siswa untuk memecahkan suatu permasalahan. Proses ini lebih banyak mendorong siswa agar dapat menguasai materi pelajaran supaya dapat menjawab semua soal ujian yang diberikan. Kenyataan menunjukkan siswa kurang aktif dalam kegiatan belajar. Siswa lebih banyak mendengar dan menulis apa yang diterangkan atau ditulis oleh guru di papan tulis.

Salah satu faktor pendukung untuk meningkatkan hasil belajar siswa adalah seorang guru dituntut dapat menggunakan strategi pembelajaran yang tepat. Guru berperan penting dalam upaya peningkatan kualitas pendidikan yang berkaitan dengan tugas pokok dan fungsinya sebagai pendidik. Untuk menyelenggarakan pembelajaran aktif, kreatif, efektif dan menyenangkan, maka guru perlu merancang perencanaan pembelajaran, pemilihan model pembelajaran yang sesuai [2].

Kondisi pembelajaran fisika seperti ini masih menggunakan model pembelajaran konvensional yang bersumber dari buku dan hanya mentransfer pengetahuan atau pikiran guru ke dalam pikiran siswa. Untuk mengatasi masalah tersebut dapat diterapkan salah satu model pembelajaran yang melatih siswa lebih aktif yakni dengan menggunakan model pembelajaran inkuiri.

Inkuiri berasal dari kata to Inquire yang berarti ikut serta, atau terlibat, dalam mengajukan pertanyaan-pertanyaan, mencari informasi, dan melakukan penyelidikan. Ia menambahkan bahwa pembelajaran inkuiri ini bertujuan untuk memberikan cara bagi siswa untuk membangun kecakapan-kecakapan intelektual (kecakapan berpikir) terkait dengan proses-proses berpikir reflektif. Model pembelajaran inkuiri adalah suatu rangkaian 
kegiatan yang melibatkan kegiatan belajar secara maksimal seluruh kemampuan siswa untuk mencari dan menyelidiki secara sistematis, kritis, logis, analitis, sehingga mereka dapat merumuskan sendiri penemuannya [3]. Dengan penuh percaya diri Jika berpikir menjadi tujuan utama dari pendidikan, maka harus ditemukan cara-cara untuk membantu individu untuk membangun kemampuan itu.

Model pembelajaran Inkuiri menekankan kepada proses mencari dan menemukan. Materi pelajaran tidak diberikan secara langsung. Peran siswa dalam model ini adalah mencari dan menemukan sendiri materi pelajaran, sedangkan guru berperan sebagai fasilitator dan pembimbing siswa untuk belajar, sehingga model inkuiri ini disebut sebagai inkuiri terbimbing.

Pembelajaran inkuiri terbimbing yaitu suatu model pembelajaran inkuiri yang dalam pelaksanaannya guru menyediakan bimbingan atau petunjuk cukup luas kepada siswa, Sebagian perencanaannya dibuat oleh guru. Dalam pembelajaran inkuiri terbimbing guru tidak melepas begitu saja kegiatan-kegiatan yang dilakukan oleh siswa. Guru harus memberikan arahan dan bimbingan kepada siswa dalam melakukan kegiatan-kegiatan sehingga siswa yang berfikir lambat atau siswa yang mempunyai intelegensi rendah tetap mampu mengikuti kegiatan-kegiatan yang sedang dilaksanakan dan siswa mempunyai intelegensi tinggi tidak memonopoli kegiata, oleh sebab itu guru harus memiliki kemampuan mengelola kelas yang baik ${ }^{[4]}$.

Model pembelajaran dengan model inquiri ini cocok diterapkan dalam pembelajaran fisika. Hal ini karena metode inkuiri lebih menekankan pada keaktifan siswa dalam belajar, siswa terlebih dahulu mengadakan kegiatan-kegiatan di laboratorium yaitu proses mengamati, mencatat hasil pengamatan, menganalisis dan menyimpulkan kegiatan praktikum yang telah dirancang oleh guru. Hal itu akan lebih membuat belajar fisika menjadi menyenangkan dan lebih berkesan, karena siswa terlibat langsung dalam proses pembelajaran.

Dari faktor-faktor di atas dapat dikatakan bahwa faktor siswa juga memegang peranan terhadap peningkatan mutu pendidikan. Sehingga penulis tertarik untuk meneliti tentang: "Peningkatan Hasil Belajar Siswa dengan Model Pembelajaran Ikuiri Terbimbing kelas XI SMA Negeri 1 Dampelas".

\section{METODE PENELITIAN}

Jenis penelitian yang digunakan pada penelitian kali ini dilihat dari teknik yang digunakan adalah penelitian kuasi eksperimen.

Variabel penelitian yang akan diteliti yaitu Peningkatan hasil belajar dengan model pembelajaran inkuiri terbimbing. Desain pada penelitian ini "Pretest-Postest Control Group Design", desain ini dapat digambarkan sebagai berikut ${ }^{[5]}$.

Tabel 1 Desain Penelitian

\begin{tabular}{cccc}
\hline Kelompok & Prates & Perlakuan & Pascates \\
\hline Eksperimen & $\mathrm{O}$ & $\mathrm{X}$ & $\mathrm{O}$ \\
Kontrol & $\mathrm{O}$ & - & $\mathrm{O}$ \\
\hline
\end{tabular}

Keterangan:

$\mathrm{X}$ : Perlakuan dengan model pembelajaran inkuiri terbimbing

O : Tes hasil belajar

Penelitian dilakukan di SMA Negeri 1 Dampelas. Penelitian dilaksanakan pada bulan Oktober-November 2014. Populasi dalam penelitian ini juga merupakan sampel dari penelitian yang terdiri dari 2 kelas yaitu kelas XI MIA 1 (31 siswa) dan XI MIA 2 (30 siswa). yang diambil dari populasi dengan menggunakan tekhnik Simple random sampling karena pengambilan anggota sampel di lakukan seara acak yang dapat di lakukan dengan cara undian. Cara demikian dilakukan bila anggota populasi dianggap homogen, dimana satu kelas sebagai kelas eksperimen dan kelas lainnya sebagai kelas control [5].

Jenis dan teknik pengambilan data pada penelitian ini berupa data kuantitatif yang diperoleh dari selisih antara nilai pretes dengan postes dalam bentuk nilai $\mathrm{N}$-gain dan dianalisis secara statistik dengan uji $\mathrm{t}$.

\section{HASIL DAN PEMBAHASAN}

Hasil Penelitian

Pengujian normalitas data penelitian ini, peneliti menggunakan Chi-kuadrat dengan kriteria penerimaan $x^{2}$ hitung $<x^{2}$ tabel, taraf signifikan $\alpha=0,05$, dan derajat kebebasan $\mathrm{dk}=\mathrm{k}-3$. Data yang digunakan untuk menguji normalitas meliputi tes awal dan tes akhir baik kelas eksperimen maupun kelas kontrol. Hasil uji normalitas tes awal dan tes akhir dari kelas eksperimen dan kelas kontrol dapat dilihat pada Tabel 2. 
ISSN 23383240

\begin{tabular}{|c|c|c|c|c|}
\hline \multirow[t]{2}{*}{ Uraian } & \multicolumn{2}{|c|}{ Tes Awal } & \multicolumn{2}{|c|}{ Tes Akhir } \\
\hline & Eksperimen & Kontrol & Eksperimen & Kontrol \\
\hline Sampel & 31 & 30 & 31 & 30 \\
\hline$x_{\text {Hitung }}^{2}$ & 1,39 & 5,02 & 0,28 & 5,49 \\
\hline $\begin{array}{c}x_{\text {tabel }}^{2} \\
\text { Ket }\end{array}$ & $\begin{array}{r}5,99 \\
\text { Norm } \\
\end{array}$ & & $\begin{array}{r}5,99 \\
\text { Norm } \\
\end{array}$ & \\
\hline
\end{tabular}

Berdasarkan uji normalitas pada Tabel 2 dengan menggunakan Chi-kuadrat, dimana untuk tes awal kelas eksperimen maupun kelas kontrol nilai $X^{2}$ hitung lebih kecil daripada nilai $x^{2}$ tabel. Begitupula untuk tes akhir, nilai $x^{2}$ hitung lebih kecil daripada nilai $x^{2}$ tabel, untuk kelas eksperimen maupun kelas kontrol. Artinya, data tes awal dan tes akhir baik di kelas eksperimen maupun kelas kontrol terdistribusi normal [6].

Pengujian data homogenitas menggunakan uji-F dengan kriteria jika Fhitung < Ftabel maka data homogen. Hasil uji homogenitas dari kelas eksperimen dan kelas kontrol dapat dilihat pada Tabel 3.

Tabel 3. Hasil Uji Homogenitas Tes Awal dan Tes Akhir

\begin{tabular}{cccc}
\hline Uraian & $\begin{array}{c}\text { Tes } \\
\text { awal }\end{array}$ & $\begin{array}{c}\text { Tes } \\
\text { Akhir }\end{array}$ & Ket \\
\hline F $_{\text {hitung }}$ & 1,07 & 1,05 & Homogen \\
Ftabel & 1,84 & 1,84 & \\
\hline
\end{tabular}

Berdasarkan Tabel 3, nilai $F_{\text {hitung }}<F_{\text {tabel. }}$ Hal ini menunjukkan bahwa data tersebut memiliki varians yang sama (homogen), atau menunjukkan bahwa kedua kelompok yang dijadikan sampel berasal dari populasi yang homogen [6].

Peningkatan hasil belajar siswa yang diperoleh dari kelas eksperimen dan kelas kontrol dihitung menggunakan persamaan $\mathrm{N}$ Gain disajikan pada Tabel 4.

Tabel 4 Hasil Uji N-gain Kelas Eksperimen dan Kelas Kontrol

\begin{tabular}{cccc}
\hline Uraian & Tes Awal & Tes Akhir & $\boldsymbol{N}$-gain \\
\hline Eksperimen & 6,9 & 10,43 & 48,43 \\
Kontrol & 6,63 & 7,57 & 30,11 \\
\hline
\end{tabular}

Berdasarkan data Tabel 4 dapat dilihat bahwa peningkatan hasil belajar untuk kelas eksperimen berada pada ketergori sedang dan untuk kelas kontrol berada pada ketegori rendah dengan nilai rata-rata $\mathrm{N}$-Gain sebesar $48,43 \%$ sedangkan untuk kelas kontrol $30,11 \%$ [6].

Uji hipotesis yang dilakukan dengan statistik parametrik (uji-t). Uji ini dimaksudkan untuk melihat perbedaan rata-rata skor peningkatan hasil belajar antara siswa yang belajar melalui model pembelajaran Inkuiri dengan siswa yang belajar melalui model pembelajaran konvensional. Teknik uji-t yang dilakukan adalah uji-t satu pihak. Uji ini digunakan untuk memastikan apakah hipotesis yang diajukan dapat diterima atau ditolak. Data hasil pengujian statistik tes akhir dapat dilihat pada Tabel 5.

\begin{tabular}{lcccc}
\multicolumn{5}{c}{ Tabel 5 Hasil Uji hipotesis } \\
\hline \multicolumn{1}{c}{ Kelas } & $\overline{\mathbf{G}}$ & $\mathbf{t}_{\text {hitung }}$ & $\begin{array}{c}\mathbf{t}_{\text {tabel }} \\
(\alpha=\mathbf{0 , 0 5})\end{array}$ & Keputusan \\
\hline Eksperimen & 44,08 & 4,402 & 1,67 & $\mathrm{H}_{1}$ diterima \\
Kontrol & 11,30 & & & \\
\hline
\end{tabular}

Berdasarkan Tabel 4 Nilai thitung $>t_{\text {tabel }}$ atau $4,402>1,67$. Hal ini menunjukkan bahwa thitung berada diluar daerah penerimaan Ho. Dengan demikian dapat disimpulkan bahwa skor ratarata $\mathrm{N}$-gain pada kelompok eksperimen lebih tinggi dari pada skor rata-rata $\mathrm{N}$ - gain pada kelompok kontrol, atau dengan kata lain model pembelajaran inkuiri terbimbing dapat menigkatkan hasil belajar siswa.

$D$

Data tersebut disajikan kembali dalam diagram agar lebih memberikan gambaran detail dan menyeluruh tentang hasil penelitian [6].

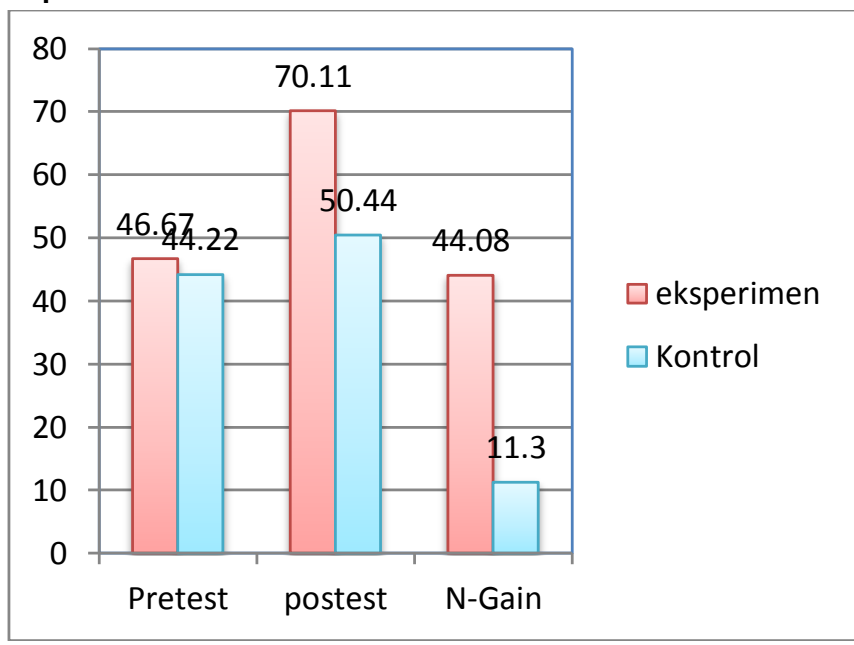

Gambar 1 Diagram Perbandingan Skor Rata-rata Tes awal, Tes akhir dan N-gain antara Kelas Eksperimen dan Kelas Kontrol

\section{Pembahasan}

Pada penelitian ini, siswa menjadi sampel penelitian diberikan tes awal (pretest) dan tes akhir (posttest) dalam bentuk pilihan ganda yang terdiri dari 15 nomor, bentuk tes ini telah divalidasi oleh validitas ahli dan validitas item tes. Tes awal yang diberikan pada kelas kontrol dan kelas eksperimen bertujuan untuk mengetahui apakah kemampuan awal kedua kelas sama atau tidak. Sedangkan tes akhir diberikan untuk mengetahui apakah terdapat peningkatan antara kemampuan awal dan kemampuan akhir siswa di kedua kelas.

Dari pretes yang diberikan kepada siswa kelas eksperimen dan kelas kontrol diperoleh 
nilai rerata skor masing-masing kelas yaitu kelas eksperimen 7.0 dan kelas kontrol 6,63 dimana diperoleh nilai rerata skor yang tidak terlalu berbeda jauh antara kelas eksperimen dan kelas kontrol sehingga dapat dikatakan bahwa kedua kelas tersebut mempunyai tingkat kemampuan awal yang sama. Setelah diberi perlakuan, kelas eksperimen dengan model pembelajaran Inkuiri dan kelas kontrol dengan model pembelajaran konvensional. Dari nilai tersebut, selanjutnya dilakukan uji homogenitas dan normalitas yang dimaksudkan untuk mengetahui kondisi awal kedua kelompok siswa. Hasil uji tersebut menunjukkan bahwa tidak ada perbedaan yang signifikan antara kelompok eksperimen dan kelompok kontrol. Ini dapat dilihat pada hasil uji statistik parametrik satu pihak yang membuktikan bahwa kedua sampel berasal dari kelompok yang homogen dan berdistribusi normal. Artinya kedua kelompok siswa memiliki kemampuan awal yang sama. Untuk uji hipotesis pada tes awal ini diperoleh hasil bahwa $\mathrm{H}_{0}$ diterima berarti bahwa pada kedua kelas tidak terdapat perbedaan kemampuan tes awal. Perolehan data tes awal yang homogen dan normal sangat diperlukan sebelum memberikan perlakuan pada kelas eksperimen, hal ini agar peningkatan hasil belajar keduanya dapat terlihat dengan jelas pada pemberian postest.

Berbeda dengan pretest yang telah dijelaskan diatas, pada postest terdapat perbedaan yang cukup signifikan, dengan menggunakan soal hasil belajar pilihan ganda sebanyak 15 nomor, yang mana tes ini juga telah divalidasi oleh validitas ahli dan validitas item tes pada materi usaha dan energi, siswa kelas eksperimen lebih banyak menjawab soal dengan benar dibanding dengan siswa pada kelas kontrol. Pada kelas eksperimen terdapat nilai rerata skor postest kelas eksperimen dan kelas kontrol masing-masing adalah kelas eksperimen 10.52 dan kelompok kontrol 7,57.

Kemudian peneliti melakukan perhitungan $\mathrm{N}$-Gain yang dimaksudkan untuk mengetahui peningkatan hasil belajar fisika antara kedua kelas dan di dapatkan masing-masing nilai rerata $\mathrm{N}$-gain kelas eksperimen $44,08 \%$ dan kelas kontrol $11,3 \%$. Terjadinya perbedaan skor rerata $\mathrm{N}$-gain antara kelas eksperimen dan kelas kontrol, disebabkan karena perolehan skor kelas eksperimen lebih tinggi di bandingkan kelas kontrol. Nilai ini menunjukkan bahwa kemampuan hasil belajar fisika pada siswa kelas eksperimen lebih tinggi daripada kelas kontrol. Dari nilai rerata $\mathrm{N}$-gain tersebut, selanjutnya siswa dikelompokkan menjadi 3 kriteria yaitu rendah, sedang, dan tinggi, dan diperoleh kriteria siswa pada masing-masing kelas yaitu kelas eksperimen 10 orang rendah, 17 orang sedang, dan 4 orang tinggi, sedangkan kriteria siswa kelas kontrol yaitu 29 orang rendah, 1 orang sedang, dan tidak terdapat siswa yang berkriteria tinggi. Dari data tersebut dapat dilihat bahwa siswa yang mengikuti model Pembelajaran Inkuiri lebih menguasai materi yang diajarkan dibandingkan dengan siswa yang mengikuti pembelajaran konvensional. Hal ini didukung oleh penelitian, Sabahiyah (2013) yang berjudul pengaruh model pembelajaran inkuiri terbimbing terhadap keterampilan proses sains dan penguasaan konsep IPA siswa kelas $\checkmark$ gugus 03 Wanasaba Lombok Timur. Hasil penelitian menunjukkan bahwa terdapat pengaruh model pembelajaran inkuiri terbimbing terhadap penguasaan konsep dan proses sains ${ }^{[7]}$.

Dengan model pembelajaran inkuiri ini siswa lebih senang belajar fisika dan lebih termotivasi, karena tidak terfokus pada teori saja melainkan mengaplikasikannya kedalam praktikum. Lain halnya dengan model pembelajaran konvensional yang terfokus pada teori sehingga mengurangi minat siswa belajar. Hal ini berpengaruh terhadap hasil belajar siswa, dimana model pembeajaran dapat berpengaruh terhadap hasil belajar siswa. Dari uji hipotesis posttest yang menyatakan bahwa pembelajaran dengan menggunakan model pembelajaran Inkuiri terbimbing dapat meningkatkan hasil belajar siswa.

\section{KESIMPULAN}

Berdasarkan hasil pengolahan data dan analisa data penelitian, maka dapat disimpulkan bahwa terdapat peningkatan hasil belajar siswa dengan model pembeljaran inkuiri terbimbing pada siswa kelas XI SMA N 1 Dampelas. Hal ini dapat diketahui melalui hasil pengujian $\mathrm{N}$-gain (peningkatan hasil belajar) sebesar $44.08 \%$ pada kelas eksperimen, sedangkan pada kelas kontrol sebesar 11,30\% dan pengujian hipotesis dengan menggunkan uji-t pada tes akhir memberikan hasil nilai thitung yang lebih besar dari tabel yaitu thitung $=4,40>$ tabel 1,67 pada taraf nyata 0,05 .

\section{DAFTAR PUSTAKA}

[1] Setyosari, Punaji. 2013. Metode Penelitian dan Pengenbangan. Malang : penerbit Kencana

[2] Siti Chodijah. Dkk. 2012. Pengembangan Perangkat Pembelajaran Fisika Menggunakan Model Guided Inquiry yang Dilengkapi Penilaian Portofolio pada 
Materi Gerak Melingkar. Padang : Jurnal Penelitian pembelajaran Fisika (JPPF).

[3] Anggareni.N.W. Dkk. 2013. Implementasi Strategi Pembelajaran Inkuiri terhadap Kemampuan Berpikir Kritis dan Pemahaman Konsep IPA Siswa SMP. Singaraja: e-Journal Program Pascasarjana Universitas Pendidikan Ganesha (vol.3).

[4] Asma. 2012. Pengaruh Model Pembelajaran Inkuiri dan Motivasi Berprestasi terhadap Hasil Belajar Fisika Siswa Kelas X SMA Negeri 1 Tinombo. Tesis: Program Pascasarjana Universitas Tadulako. Palu

[5] Sugiyono. 2014. Statistika untuk Penenlitian. Bandung : Penerbit alfabeta.

[6] Vitayana, Dian. 2015: Peningkatan Hasil Belajar dengan Model pembelajaran Inkuiri Terbimbing pada Siswa Kelas XI SMA Negeri 1 Dampelas. : Skripsi, Program Reguler Universitas Tadulako. Palu.

[7] Sabahiyah, A. A. I. N. Dkk. 2013. Pengaruh Model Pembelajaran Inkuiri Terbimbing terhadap Keterampilan Proses Sains dan Penguasaan Konsep IPA Siswa Kelas V Gugus 03 Wanasaba Lombok Timur. Singaraja: e-Journal Program Pascasarjana Universitas Pendidikan Ganesha (vol.3). 